\title{
E-Learning Facilities Availability, Usability and Adaptability as Predictors of Job Effectiveness among Academic Staff of University of Ibadan
}

\author{
Sunday Nnamdi Okocha \\ Monica Ngozi Odinko \\ University of Ibadan, Nigeria
}

\begin{abstract}
Preliminary investigations reveal that some academic staff find it difficult to adapt use of elearning facilities for delivery academic duties which could lead to job ineffectiveness. The study, investigated the extent to which e-learning facilities availability, usability and adaptability predict job effectiveness among academic staff of University of Ibadan in order to ensure effective delivery of academic duties. Non-experimental design of correlational research type was adopted. Population comprised lecturers in Faculties, Institutes and Centres in University of Ibadan. Purposive sampling technique was used to select 14 Faculties (48 Departments), 3 Institutes and 2 Centres which are academic units. Five lecturers were randomly selected in each unit, given sample of 265 lecturers. Data was collected using four instruments developed and content validated and ordinal alpha reliability estimated. Three research questions were raised. Data analysis was done using PPMC and Multiple regression. Results showed that availability, usability and adaptability of e-learning facilities had positively significant influence on job effectiveness among academic staff of the University of Ibadan. The study recommended that academic staff should adapt the use of e-learning facilities into their academic work to enhance job effectiveness.
\end{abstract}

Keywords: E-learning, Adaptability, Acceptance, Proficiency, Training

\section{Introduction}

The application of Information and Communication Technological (ICT) tools in teaching and learning is not new innovation. Other countries, especially developed ones, have been employing its usage. ICT refers to many technologies such as: electronic boards, internet, projector, computer, application software, radio, television, cell phones, hardware, satellite, video conferencing among others. In Nigeria, experience and observation has shown that academic institutions like the National Open University (NOUN) and University of Ibadan Distance Learning Centre as well as other higher institutions who run Distance Education (DE) 
have used a blended learning approach. This approach has potentially made ICT a powerful tool for educational change and reform (Akarowhe, 2017). ICT in education, which is the focus of this study, involves adaptability to the use of electronic learning facilities for delivery of academic duties by academic staff of higher institution.

The ever-dynamic trends in education encourage greater job effectiveness through better content delivery. There are pressures for universities to adopt e-learning facilities. This requires staff and faculty to adapt to new skills and techniques in teaching, presenting, researching and publishing.

Adaptability is contextualized in this study as acceptance, proficiency, and engagement in training and retraining of academic staff of higher institutions in the use of the e-learning facilities. Bai and Ertmer (2008) establish that effective use and integration of ICTs in teaching by teachers depends on the teachers' attitude towards computer technology.

Acceptance of technology could influence the way teachers use it. In other words, if they have negative dispositions towards ICTs, they are unlikely to integrate and adapt ICTs in their teaching, researching, presenting and publishing activities. Acceptance of e-learning facilities is as a result of the emergence of ICTs and internet connectivity have improved user's ingenuity and opportunities. Societies now depend on real-time information for proactiveness given the effects of environmental changes (Zhang, et al, 2010; Al-Gahtani, 2016; Eze \& Chinedu-Eze, 2018). Rosnaini and Mohd-Arif (2010) show that a minority of teachers were knowledgeable in basic ICT. However, some of them only averaged a minimal knowledge in ICTs. This scenario clearly shows that the key factor in making ICT programs successful in school is to upgrade the level of ICT knowledge among teachers (Moganashwari \& Parilah, 2013).

Proficiency in use of e-learning facilities has emerged as an important tool for university lecturers' efficiency in the teaching-learning as well as more effective social interactions that are valued by employers. According to The United Nations Educational, Scientific and Cultural Organization (UNESCO, 2011), ICT skills are very important and are used as gate-skills by employers when evaluating job applications. E-learning facilities skills are therefore important for lecturers in order to utilise software tools and flexibly adapt to change in ICT infrastructure and applications (UNESCO 2014). It is expected that lecturers should not only be able to use ICTs but become comfortable in using them if they are to participate fully in the contemporary tertiary institution life and perform their everyday tasks and be satisfied on their job.

Lecturers at higher education institutions can become more effective in their daily 
academic activities while training in an e-learning facility. Staff members have to be trained to deal with different opportunities made possible by use of ICTs in education, including virtual universities, and distance education, which become feasible alternative platforms for HEIs (AlWehaibi, K., Al-Wabil, A. Alshawi, A., \& Alshöankity, 2010). Adequate professional development for lecturers on the adoption of technology in their academic activities will empower them to use the tool to improve their job effectiveness.

Job effectiveness is very important in maintaining human resources and academic activities.

The activities could be enhanced through adapting to the use to e-learning facilities. Akpan (2014) submits that the effectiveness of lecturers is enhanced with e-learning facilities. In academia, job effectiveness could be seen as a cornerstone for a healthier university system. Academic staff are seen as great assets as well as one of the major stakeholders in the university industry whose main work is to teach young generations of students to acquire skills and knowledge for growth and development, carry out research to inform and uncover solutions to problems, do presentations to enlighten and train the societies regarding their discoveries through research and publish their findings at conferences, seminars, trainings and workshops for large dissemination and consumption.

\section{Statement of the Problem}

Even though there is a constant advancement of technologies, academic staff, who are accustomed to not using new ICT tools, tend to avoid using the e-learning facilities. However, it is not clear if some of the academic staff, who opted to use the e-learning facility but are not proficient, seek adequate training to be more effective in their ICT usage. Previous studies on adaptability to e-learning facilities and job effectiveness among academic staff in higher institutions appears to be limited, except on open and distance learning education and secondary schools. None of the studies examined the extent to which availability, usability and adaptability of e-learning facilities could predict job effectiveness of academic staff in tertiary institutions. This study, therefore, investigated the extent to which e-learning facilities availability, usability and adaptability could predict job effectiveness (for teaching, researching, presenting and publishing their academic write-ups) among academic staff of University of Ibadan.

\section{Research Questions}

1. What is the strength and direction of relationship among e-learning facilities availability, usability, adaptability (acceptance, proficiency, training and retraining) 
and job effectiveness of academic staff in University of Ibadan?

2. To what extent would e-learning facilities (electronic board, computer, internet, projector, application software) availability, usability and adaptability jointly predict job effectiveness of academic staff in University of Ibadan?

3. What is the relative contribution of e-learning facilities availability, usability, and adaptability to job effectiveness of academic staff in University of Ibadan?

\section{Literature Review}

The study was anchored on Technology Acceptance Model (TAM) by Davis (1989) with two important variables, Perceived Usefulness (PU) and Perceived Ease of Use (PEOU), as both determine the adoption of technology and user intentions to develop new skills and adaptability to the use of e-learning facilities as a motivating factor to job effectiveness.

Tertiary institutions are welcoming the use of ICT in more proficient and competitive processes for both administrative and services delivery (Suryawanshia \& Narkhedeb, 2015). These days, ICTs for education have incorporated a wide range of technologies such as virtual reality, video-conferencing, handheld computers, digital cameras, World Wide Web (WWW) and digital libraries (Mathevula \& Uwizeyimana, 2014). Also, networking of computer devices has provided a method of sharing knowledge locally and internationally such as electronic learning (Asabere, N., Togo, G. \& Acakpovi, A., 2017). According to Abbad, M. M., Morris, D., \& de Nahlik, C. (2009), e-learning is any learning that is enabled electronically. Electronic learning facilities could be described as the use of digital technologies such as electronic boards, internet, projector, computer, application software for delivering teaching, presentation, research and publication activities particularly in higher educational system.

Technology today has increasingly become a vital element for universities. As such, teachers need to equip and acquaint themselves with the necessary skills needed to adjust to the changes brought about by technology (Philip, A., Oluwaghema, C. \& Oluwaranti, A., 2010; Voogt 2010; Voogt, J., Fisser, P., Pareja Roblin, N., Tondeur, J. \& Van Braak, J., 2013). In recent times, the limitations of distance have been bridged by e-learning facilities.

Interactions can go on between teacher and several students simultaneously through virtual classrooms. The use of modern technologies such as electronic boards, computers, application programs, becomes easy for teachers and students to get connected, thereby making teaching and learning more interactive in innovative ways. It could be difficult, if not impossible, to achieve job effectiveness among academic staff without the use and adaptability of e-learning facilities. Learning processes and the introduction of ICT in schools was driven 
by global forces beyond school-based decision making (Voogt, 2010; Voogt et al 2013).

The expansion of technology in wide areas including educational institutions was an intention to improve teaching and learning environment (Al-Qahtani \& Higgins, 2012). Yet, the development of ICT policies in Africa, particularly Nigeria, often strives to match international ICT policy in education. Despite the huge investments in the integration of ICT by numerous higher institutions, the practical use of ICT facilities by teachers was in preliminary stages with little significance in the educational outcome (Howie, 2010).

The introduction of e-learning facilities in Nigeria universities has been focused on equipping teachers and students with the technological knowledge to use ICT (Ndongfack, 2015). This could result in an improper usage of electronic learning facilities in education. The integration of e-learning facilities properly for teaching, presentation, research and publication processes among academic staff of Nigeria universities seems to be at elementary stage. It is therefore necessary to find out how e-learning facilities are used as a tool to facilitate or enhance job effectiveness among academic staff in the university system. Academic staffs of universities still actively resist the use of modern technology in teaching (Ndibalema, 2014). This could suggest that they are more comfortable with the orthodox instructional method of teaching and find no relevance for the use of ICT facilities, which could also be that they find it difficult to adapt to the use of e-learning facilities.

The term adaptation could also be referred to as adaptability which is the possibility for lecturers to personalize e-learning facilities to their own academic activities. Adaptability to use of e-learning facilities has to do with the process of change by which lecturers become better suited to the use of electronic facilities. Nyika (2015) found that many lecturers lack ICT competencies. As a result, they do not prepare students adequately for the use of ICTs as teaching, learning and communication tools. It is necessary to adapt to the technicalities of elearning facilities such as the electronic board, computer, projector, application program, internet in order to carry out specific activities that will ensure job effectiveness among academic staff. Adaptation to e-learning facilities in this study was defined in terms of acceptance, proficiency in, training in and retraining in the use of e-learning facilities.

Acceptance of e-learning facilities could refer to consenting to receive or accept the innovations of electronic learning facilities for carrying out academic activities. Organizations have attempted to cope with differing and updating technologies by making huge investments in state-of-the-art ICTs. Essentially, organizations need to create a competitive advantage amidst often decreasing costs of technologies in the contemporary information systems market (Maldonado, et al, 2011; Awa, Eze, et al, 2011; Bhuasiri, et al, 2012; Eze, et al, 2013). 
According to Sharma, et al. (2009), e-learning places a high demand on learners who have to be more proactive and disciplined than traditional face-to-face education. This is true for lecturers in higher institutions as well. However, limitations in bandwidth, access to network resources, as well as development and retention of human resource involved in ICT, poses a key challenge especially in African tertiary institutions (Khan et al., 2012).

Proficiency for universities is the extent of advancement of innovative skills by instructors for using e-learning facilities when delivery academic activities. Proficiency in use of e-learning facilities has emerged as an important tool for university lecturers' efficiency in the teaching-learning as well as for social interactions, which in turn, leads to job effectiveness. According to Bordbar (2010), teachers' computer competence is a major predictor of integrating ICT in teaching. In the same vein, the advantage of virtual learning environments like the interactive whiteboard and the computer, projector, application software, etc., which injects flexibility in university teaching and learning, calls on academic staff to be ICT proficient. The effectiveness in use of e-learning facilities as a means of delivery of academic activities becomes necessary for academic staff when they are making presentations to a group or audience that require these processes to be used in $21^{\text {st }}$ Century universities. It was argued that fear of failure and lack of ICT knowledge have been cited as some of the reasons for teachers' lack of confidence for adopting and integrating ICT into their teaching (Balanskat, et al. 2007).

Training in the use of e-learning facilities could either be sponsored by the institution or personally to enable academic staff to learn and be able to adapt to using the e-learning facilities in order to improve their ICT knowledge and productivity. Competencies that need to be developed at the early stage of ICT could include: production of multimedia course materials, data analysis, e-library, video conferencing, networking and e-payments etc. Archibong et al (2010) in a study on ICT competence among academic staff in universities found that majority of the academic staff were funded for their ICT training and funding was made available for inadequate ICT facilities, but excess work load and funding were also identified as major challenges to ICT usage among academic staff.

Similarly, Saekow and Samson (2011) found a significant relationship between the activeness of ICT training programmes and lecturers' self-perception of competence in working with computers and noted that strong training programmes were necessary to equip lecturers with appropriate ICT skills, as well as training on course delivery and administration skills within the new environment. 


\section{Methodology}

This study adopted a non-experimental design of correlational research. This was decided because the researcher had no direct control on the independent variables as their manifestation has already occurred. The study was comprised of lecturers in faculties, institutes and centres at the University of Ibadan. From the existing strata, a purposive sampling technique was used to select 14 faculties which consisted of 48 Departments, 3 Institutes and 2 Centres which are academic units. Five lecturers (from all cadres) were randomly selected in each unit, for a given total sample of 265 lecturers used as the samples for this study. This was done during the University of Ibadan 2016-2018 Calendar.

\section{Instrumentation and Data Collection}

Four instruments were used for data collection: Electronic Learning Facility Checklist (ELFC) which contains eighteen (18) items with a response format of Not Available (NA) 1 and Available (A) 2, to ascertain the types of e-learning facilities at the disposal of the academic staff. The Electronic Learning Facility Usability Rating Scale (ELFURS) contains eighteen (18) items with a response format of Never (NV) 1, Seldom (SM) 2, Often (OF) 3, and Very Often (VO) 4, to ascertain the types of e-learning facilities often used by academic staff. The Adaptability to Electronic Learning Facility Use Questionnaire (AELFUQ) has three subsections with a response format of Not Very Like Me (NVLM) 1, Not Like Me (NLM) 2, Much Like Me (MLM) 3 and Very Much Like Me (VMLM) 4.

The first sub-section contains twenty-two (22) items used to elicit information on a acceptance level of e-learning facilities. The second sub-section contains thirty-nine (39) items used to elicit information on level of proficiency in the use of e-learning facilities while the third sub-section contains nine items used to elicit information on the extent of training and retraining that was engaged in by academic staff. The Job Effectiveness Lecturer's Questionnaire (JELQ) contains twenty-three (23) items with response formats of Not Very Like Me (NVLM) 1, Not Like Me (NLM) 2, Much Like Me (MLM) 3 and Very Much Like Me (VMLM) 4.

These instruments were developed and trial tested by the researcher on a smaller sample different from those of this study to ascertain validity and reliability of the instruments. Ordinal alpha reliabilities of ELFURS is 0.86, AELFUQ is 0.97 and JELQ is 0.95 (These reliabilities estimates show excellent consistencies). The researchers visited the academic staff in the sampled academic units to administer the instruments and the data collected were analysed using Pearson Product Moment Correlation for research question 1 and multiple regressions 
for research questions 2 and 3.

\section{Results}

Research Question One: What is the strength and direction of the relationship among elearning facilities availability, usability, adaptability (acceptance, proficiency, training and retraining) to e-learning facilities and job effectiveness of academic staff in University of Ibadan?

Table 1 presents the result of Pearson Product Moment Correlation coefficient for the relationship among e-learning facilities availability, usability, adaptability to e-learning facilities acceptance, adaptability to e-learning facilities proficiency, adaptability to e-learning facilities training and retraining and job effectiveness of academic staff in University of Ibadan.

Table 1:

Intercorrelation Matrix of E-Learning Facilities Availability, Usability,

Adaptability to E-Learning Facilities and Job Effectiveness

\begin{tabular}{lllllll}
\hline Variables & ELfA & ELfU & AELA & AELP & AELT & JE \\
\hline ELFA & 1 & & & & & \\
ELFU & $0.458^{* *}$ & 1 & & & & \\
AELA & $0.234^{* *}$ & $0.442^{* *}$ & 1 & & & \\
AELP & $0.262^{* *}$ & $0.400^{* *}$ & $0.743^{* *}$ & 1 & & \\
AELT & $0.164^{* *}$ & $0.254^{* *}$ & $0.392^{* *}$ & $0.388^{* *}$ & 1 & 1 \\
JE & $0.362^{* *}$ & $0.535^{* *}$ & $0.665^{* *}$ & $0.646^{* *}$ & $0.448^{* *}$ & 1 \\
\hline
\end{tabular}

** Significant @ p $<0.01$ and 0.05; N = 265

Note: ELFA = E-learning Facilities Availability; ELFU = E-learning Facilities Usability; AELA = Adaptability to E-learning Acceptance; AelP = Adaptability in E-learning Proficiency; Aelt $=$ Adaptability to E-learning Training and Retraining; JE $=$ Job Effectiveness

From Table 1, it can be observed that there is no multi-collinearity ( $r>0.90)$ among the variables of the study, as no variable(s) provide linearly or correlated relationship. Also, the intercorrelation matrix showing the correlation coefficients of the predictors (ELFA, ELfu, Aela, Aelp, Aelt) and criterion variable (JE) reveals moderate significant positive relationship between e-learning facilities availability and job effectiveness $(r=0.362 ; p<0.05(0.001))$. In the same vein, results reveals that e-learning facilities usability had moderate significant positive relationship with job effectiveness $\left(\mathrm{r}=0.535 ; \mathrm{p}<0.05_{(0.001)}\right)$. Likewise, results reveals that adaptability to e-learning acceptance $\left(\mathrm{r}=0.665 ; \mathrm{p}<0.05_{(0.001)}\right)$ and adaptability to e-learning 
proficiency $\left(\mathrm{r}=0.646 ; \mathrm{p}<0.05_{(0.001)}\right)$ had high significant positive relationships with job effectiveness. Also, results reveal that, adaptability to training and retraining was moderately significant with job effectiveness $\left(r=0.448 ; \mathrm{p}<0.05_{(0.001)}\right)$.

This implies that all the variables considered correlate and may influence job effectiveness of academic staff. Again, Table 1 reveals that e-learning facilities availability $\left(\mathrm{r}=0.164 ; \mathrm{p}<0.05_{(0.008)}\right)$; e-learning facilities usability $\left(\mathrm{r}=0.254 ; \mathrm{p}<0.05_{(0.001)}\right)$; adaptability to elearning acceptance $\left(\mathrm{r}=0.392 ; \mathrm{p}<0.05_{(0.001)}\right)$; and adaptability to e-learning proficiency $\left(\mathrm{r}=0.388 ; \mathrm{p}<0.05_{(0.001)}\right)$ had weak significant positive relationships with job effectiveness. This implies that all the variables considered may influence adaptability to training and retraining in the use of e-learning facilities among academic staff.

Also, in Table 1, it could be observed that, e-learning facilities availability ( $\mathrm{r}=0.262$; $\left.\mathrm{p}<0.05_{(0.001)}\right)$, e-learning facilities usability $\left(\mathrm{r}=0.400 ; \mathrm{p}<0.05_{(0.001)}\right)$ had weak significant positive relationships while adaptability to e-learning facilities acceptance $(r=0.743$; $\left.\mathrm{p}<0.05_{(0.001)}\right)$ had high significant positive relationship with e-learning facilities proficiency. Thus, the availability, usability and acceptance of e-learning facilities are major influencing factors for being adapted and becoming proficient in the use of e-learning facilities among academic staff at University of Ibadan.

Furthermore, it could be observed from the results that the e-learning facilities availability $\left(\mathrm{r}=0.234 ; \mathrm{p}<0.05_{(0.001)}\right)$ and e-learning facilities usability $\left(\mathrm{r}=0.422 ; \mathrm{p}<0.05_{(0.001)}\right)$ had weak significant positive relationship with the adaptability to acceptance of e-learning facilities, which implies that when e-learning facilities are available and adequately used by academic staff, there would be a wide acceptability of the use of such facilities.

Lastly, results reveal a moderate significant positive relationship between availability of e-learning facilities and its usage $\left(r=0.458 ; \mathrm{p}<0.05_{(0.001)}\right)$. This implies that the provisions of e-learning facilities will greatly increase the usage of e-learning facilities among academic staff in the University of Ibadan.

The results in the intercorrelation matrix table on the strength and direction of relationship among e-learning facilities availability, usability, adaptability (acceptance, proficiency, training and re-training) and job effectiveness among academic staff in University of Ibadan revealed that there is no multi-collinearity among the variables. The result of the relationship between availability of e-learning facilities and job effectiveness among academic staff indicate significant positive relationship, which implies that provisions of e-learning facilities in the Faculties, Institutes, and Centres will increase the job effectiveness of academic staff. This result is in line with that of Akinnubi, et al. (2012) which affirmed that, availability 
of computers and other ICT facilities in selected secondary schools in Kwara State showed a significant relationship with teacher's job effectiveness.

Also, the result of the relationship between usage of e-learning facilities and job effectiveness among academic staff revealed significant positive relationship. This suggests that the more consistent use of e-learning facilities for academic activities, the better or more effective academic staff will become on their job. The result is also consistent with that of Osman (2014) who investigated the use of Information and Communication Technologies (ICTs) and factors that influence use of ICT among staff members of Khartoum State Universities in Sudan which revealed that ICT was widely used by most staff members.

In like manner, the result of the relationship between adaptability to e-learning acceptance and job effectiveness among academic staff indicated a high significant positive relationship. This is an indication that academic staff sees the acceptance of e-learning facilities as key to their academic work in order to be able to cope with the trends of the 21 st Century. This result supports that of Guma et al, (2013) who revealed that teaching staff and administrators had a strong desire to integrate ICT into teaching learning processes.

Similarly, the results of the relationship between adaptability to e-learning proficiency and job effectiveness had a high significant positive relationship. In other words, for academic staff to be proficient in the use of e-learning facilities in carrying out academic work, such staff would become effective in the discharge of academic duties because of the skills and expertise they learn in using e-learning facilities. However, according to the study of Nyika (2015), many lecturers lack ICT competences, hence, they do not prepare students adequately for use of ICTs as teaching and learning communication tools.

Furthermore, the result of this study support that of Guma, et al. (2013) who affirmed that there was a significant relationship between computer literacy and teacher job effectiveness. The relationship between adaptability to e-learning training and retraining and job effectiveness among academic staff revealed a significant moderate positive relationship. It is expected that the more training and retraining on e-learning facilities, the more dynamics and effective the user becomes in using it for various activities. This was in line with the result of Ogundele and Etejere (2013) who revealed that computer literacy encourages appreciation and utilisation of computers during teaching processes which in turn aid teachers' job effectiveness. Their study also revealed that computer literate teachers perform better than noncomputer literate teachers in schools, as this aroused interest in teaching.

Research Question Two: To what extent would e-learning facilities (electronic board, computer, internet, projector, application software) availability, usability and adaptability 
(acceptance, proficiency, training and retraining) jointly predict job effectiveness of academic staff in University of Ibadan?

Table 2 presents the results of joint effect of all the independent variables: e-learning facilities availability, e-learning facilities usability and adaptability on job effectiveness of academic staff in University of Ibadan.

\section{Table 2}

Regression Summary and ANOVA of Availability, Usability, Adaptability

and Job Effectiveness of Academic Staff in University of Ibadan

\begin{tabular}{ll}
\hline Multiple R & $=0.764$ \\
R Square & $=0.583$ \\
Adjusted R Square & $=0.575$ \\
Standard Error & $=7.264$
\end{tabular}

\section{Analysis of Variance}

\begin{tabular}{llllll}
\hline Source of Variance & Sum of Square & Df & Mean Square & F & Sig. \\
\hline Regression & 19142.997 & 5 & 3828.599 & & \\
Residual & 13664.980 & 259 & 52.761 & 72.566 & 0.001 \\
Total & 32807.977 & 264 & & & \\
\hline
\end{tabular}

Significant @ $\mathrm{p}<0.05 ; \mathrm{N}=265$

From Table 2, the joint effect of all the independent variables on job effectiveness of academic staff in University of Ibadan, reveals multiple correlation coefficients of $\mathrm{R}=0.764$, $\mathrm{R}^{2}=0.583$, Adj $\mathrm{R}^{2}=0.575$. The multiple correlations $(\mathrm{R})$ of 0.764 , indicate a high positive relationship among the independent variables (Availability, Usability and Adaptability) to elearning facilities and job effectiveness of academic staff. Hence, the predictor variables are highly relevant in predicting the job effectiveness of academic staff in the sample academic units of University of Ibadan.

More so, as shown in Table 2, the combination of all the independent variables (Adj $\mathrm{R}^{2}$ ), accounted for $57.5 \%$ of the variation observed in job effectiveness among academic staff in the sampled academic units in University of Ibadan. The remaining $42.5 \%$ could be due to factors and residuals in the model that are not considered in this study. Furthermore, the ANOVA results from the regression analysis also show that there was significant effect of the independent variables on the dependent $\left(\mathrm{F}_{(5,259)}=72.566 ; \mathrm{p}<0.05(0.001)\right)$.

Research Question Three: What is the relative contribution of e-learning facilities availability, usability, and adaptability (acceptance, proficiency, training and retraining) to job effectiveness 
of academic staff in University of Ibadan?

Table 3 presents the results of relative contribution of e-learning facilities availability, usability, and adaptability to job effectiveness of academic staff in University of Ibadan.

\section{Table 3:}

Relative Contribution of E-Learning Facilities Availability, Usability, and Adaptability to Job Effectiveness of Academic Staff in University of Ibadan

\begin{tabular}{|c|c|c|c|c|c|c|}
\hline \multirow[t]{3}{*}{ Variables } & \multirow{2}{*}{\multicolumn{2}{|c|}{$\begin{array}{l}\text { Unstandardised } \\
\text { Coefficients }\end{array}$}} & \multirow{2}{*}{$\begin{array}{l}\text { Standardised } \\
\text { Coefficients }\end{array}$} & \multirow{3}{*}{$\mathrm{T}$} & \multirow{3}{*}{ Rank } & \multirow{3}{*}{ Sig. } \\
\hline & & & & & & \\
\hline & B & Std. Error & Beta & & & \\
\hline (Constant) & -4.674 & 6.094 & & -0.767 & & 0.444 \\
\hline $\begin{array}{l}\text { E-learning Facilities } \\
\text { Availability }\end{array}$ & 0.475 & 0.211 & 0.102 & 2.254 & $5^{\text {th }}$ & 0.025 \\
\hline E-learning Facilities Usability & 0.264 & 0.060 & 0.215 & 4.380 & $3^{\text {rd }}$ & 0.001 \\
\hline $\begin{array}{l}\text { Adaptability to E-learning } \\
\text { Acceptance }\end{array}$ & 0.325 & 0.068 & 0.297 & 4.750 & $1^{\text {st }}$ & 0.001 \\
\hline $\begin{array}{l}\text { Adaptability in E-learning } \\
\text { Proficiency }\end{array}$ & 0.148 & 0.036 & 0.249 & 4.068 & $2^{\text {nd }}$ & 0.001 \\
\hline $\begin{array}{l}\text { Adaptability to E-learning } \\
\text { Training and Retraining }\end{array}$ & 0.470 & 0.128 & 0.163 & 3.680 & $4^{\text {th }}$ & 0.001 \\
\hline
\end{tabular}

Significant @ $\mathrm{p}<0.05 ; \mathrm{N}=265$

From Table 3, it appears that all the predictor variables: adaptability to e-learning acceptance $\left(\beta=0.297 ; \mathrm{t}=4.750 ; \mathrm{p}<0.05_{(0.001)}\right)$; adaptability to e-learning proficiency $(\beta=0.249$; $\left.\mathrm{t}=4.068 ; \mathrm{p}<0.05_{(0.001)}\right)$, e-learning facilities usability $\left(\beta=0.215 ; \mathrm{t}=4.380 ; \mathrm{p}<0.05_{(0.001)}\right)$, adaptability to training and retraining $\left(\beta=0.163 ; \mathrm{t}=3.680 ; \mathrm{p}<0.05_{(0.001)}\right)$ and e-learning facilities availability $\left(\beta=0.102 ; \mathrm{t}=2.254 ; \mathrm{p}<0.05_{(0.001)}\right)$ contributed significantly to job effectiveness of academic staff of University of Ibadan.

However, adaptability to e-learning acceptance was the most influencing predictor, followed by adaptability in e-learning proficiency, followed by e-learning facilities usability, followed by adaptability to e-learning training and retraining and lastly by e-learning facilities availability to job effectiveness of academic staff in the sample academic units in University of Ibadan.

The result on the composite contribution revealed a very high positive influence of the 
predictor variables (availability, usability and adaptability of e-learning facilities) to the criterion variable (job effectiveness). The result further showed that variance observed on the criterion variable due to the influence of the predictor variables accounted for more than fifty percent. The results on the relative contribution of e-learning facilities availability, usability and adaptability to job effectiveness of academic staff in University of Ibadan revealed that all the predictor variables significantly contributed to job effectiveness of academic staff with adaptability to e-learning acceptance contributing most significantly, followed by adaptability to e-learning proficiency, usability, adaptability to training and retraining and availability of elearning facilities respectively.

This corroborates the assertion of Bai and Ertmer (2008) that effective and integration of ICTs in teaching by teachers depends on the teachers' attitude towards ICT technology. In other words, their acceptance and proficiency in technology influence the way they use it. This implies that, if they develop positive acceptance towards ICTs, they are likely to integrate and adapt ICTs into teaching, research, presentation and publication activities. The result of this study also affirmed with that of Bordbar (2010), that teacher competence is a major predictor of integrating ICT in teaching. The result also supports that of Archibong and Effiom (2009) who submits that academic staff ICT usage is of much help to them in the areas of upgrading their knowledge, research and publication.

\section{Implication for Tertiary Institutions}

The findings of this study revealed the need for lecturers to be dynamic and flexible in the use of e-learning facilities in order to have maximum productivity in their academic pursuits. School administrators should see the need to increase productivity of academic staff through the introduction of e-learning facilities in faculties, institutes and centres in the University.

\section{Conclusion and Recommendations}

This study has been able to establish that the availability and usability of e-learning facilities can ensure adaptability in the use of these facilities among academic staff in enhancing their job effectiveness in higher institutions. The main inference drawn from this study was that availability, usability and adaptability in terms of acceptance, proficiency, training and retraining on e-learning facilities has positively and significantly influenced job effectiveness among academic staff of the University of Ibadan.

It could be concluded therefore, that availability, usability and adaptability of e-learning 
facilities has been revealed to be potent predictors of job effectiveness among academic staff in teaching, research, presentation and publication. Based on the findings of this study, it is recommended that academic staff should recognise the importance of adapting to the use of elearning facilities in order to enhance their job effectiveness and that government/school administrators should endeavour to support faculties, institutes and centres within the institution with funds to enable them acquire technological tools that could enhance job effectiveness of staff.

\section{References}

Abbad, M. M., Morris, D., \& de Nahlik, C. (2009). Looking under the Bonnet: Factors affecting student adoption of e-learning systems in Jordan. The International Review of Research in Open and Distance Learning.

Akarowhe, K. (2017). Information Communication Technology (ICT) in the educational system of the third world countries as a pivotal to meet global best practice in teaching and development. Am J Compt Sci Inform Technol 5:2. doi: 10.21767/23493917.100010.

Akinnubi, O. P., Sule, A. O. \& Yisa, H. M. (2012). Computer literacy and teacher job effectiveness in Kwara State secondary schools. Academic Research International. Vol. 2, No. 3.

Akpan, C. P. (2014). ICT competence and lecturers' job efficacy in universities in Cross River State, Nigeria. International Journal of Humanities and Social Science, 4(10), 259-266. http://www.ijhssnet.com/journals/Vol_4_No_10_August_2014/31.pdf.

Al-Gahtani, S. S. (2016). Empirical investigation of e-learning acceptance and assimilation: A structural equation model. Applied Computing and Informatics, 12(1), 27-50.

Al-Qahtani, A. A. Y. \& Higgins, S. E. (2012). Effects of traditional, blended and e-learning on students' achievement in higher education. Journal of Computer Assisted Learning, Vol. 29(3) 220-234.

Al-Wehaibi, K., Al-Wabil, A. Alshawi, A., \& Alshöankity (2010). Barriers to internet adoption among Faculty in Saudi Arabian Universities.

Archibong, I. A. \& Effiom, D. O. (2009). ICT in University education: Usage and challenges among academic staff. African Research Review. International Multi-Disciplinary Journal, Ethiopia, Vol. 3 (2), 404-414.

Asabere, N., Togo, G. \& Acakpovi, A. (2017). AIDS: An ICT model for integrating teaching, learning and research in Technical University Education in Ghana. International 
Journal of Education and Development using Information and Communication Technology (IJEDICT), 2017, Vol. 13, Issue 3, 162-183.

Awa, H. O., Eze, S. C., Urieto, J. E. \& Inyang, B. J. (2011). The upper echelon theory (UET): A major determinant of information technology adoption by SMEs in Nigeria. Journal of Systems and Information Technology, 15(6), 278-295.

Bai, H. \& Ertmer, P. A. (2008). Teacher educators' beliefs and technology uses as predicators of pre-service teachers' beliefs and technology studies. Journal of Teacher Education and Technology, 16 (1), 93-112.

Balanskat, A., Blamire, R. \& Kafal, S. (2007). A review of studies of ICT impact on schools in Europe. European Schoolnet.

Bhuasiri, W., Xaymoungkhoun, O., Zo, H., \& Rho, J. (2012). Critical success factors for elearning in developing countries: A comparative analysis between ICT experts and faculty. Computers \& Education, 58, 843-855.

Bordbar, F. (2010). English teachers' attitudes toward computer-assisted language learning. International Journal of Language Studies, Vol. 4, no. 3, 27-54.

Davis, F. D. 1989. Perceived usefulness, perceived ease of use, and user acceptance of information technology. MIS Quarterly. Vol. 13 Issue 3.

Eze, S. C. \& Chinedu-Eze, C. V. (2018). Examining information and communication technology (ICT) adoption in SMEs: A dynamic capabilities approach. Journal of Enterprise Information Management, 31(2), 338-356.

Eze, S. C., Awa, H., Okoye, J., Emecheta, B. \& Anazodo, R. (2013). Determinant factors of information communication technology (ICT) adoption by government-owned universities in Nigeria: A qualitative approach. Journal of Enterprise Information Management, 26(4), 427-443.

Guma, A., Faruque, A. \& Haolader, K. M. (2013). The role of ICT to make teaching-learning effective in higher institutions of learning in Uganda. International Journal of Innovative Research in Science, Engineering and Technology. Vol. 2, Issue 8.

Howie, S. J. (2010). ICT-supported pedagogical policies and practices in South Africa and Chile: emerging economies and realities. Journal of Computer Assisted Learning, 26: 507-522. doi: 10.1111/j.1365-2729.2010.00377.x.

Khan, M., Hossain, S., Hasan, M. \& Clement, C. K. (2012). Barriers to the introduction of ICT into education in developing countries: the example of Bangladesh. International Journal of Instruction, vol. 5, No. 2, 61-80.

Maldonado, U., Khan, G., Moon, J. \& Rho, J. (2011). E-learning motivation and educational 
portal acceptance in developing countries. Online Information Review. 35, 66-85.

Mathevula, M. D. \& Uwizeyimana, D. E. (2014). The challenges facing the integration of ICT in teaching and learning activities in South African rural secondary schools. Mediterranean Journal of Social Sciences, Vol. 5, No. 20, 1087-1097.

Moganashwari, K. \& Parilah, M. S. (2013). Knowledge, attitude and use of ICT among ESL teachers. Proceeding of the Global Summit on Education. 11-12 March 2013, Kuala Lumpur. Organized by WorldConferences.net.

Ndibalema, P. (2014). Teachers' attitudes towards the use of information communication technology (ICT) as a pedagogical tool in secondary schools in Tanzania: The case of Kondoa District. International Journal of Education and Research, 2(2), 1-16.

Ndongfack, M. N. (2015). Mastery of active and shared learning processes for technopedagogy (MASLEPT): A model for teacher professional development on technology integration. Creative Education, 6, 32-45.

Nyika, R. (2015). Adapting to the changes necessitated by ICTs in education and training: An assessment of the use of ICTs in the division of education, training and strategic studies at Gweru Polytechnic. Greener Journal of Educational Research, 5(6):215-222.

Ogundele, M. O. \& Etejere, P. A. O. (2013). Computer literacy and secondary school teachers' job effectiveness in Kwara State, Nigeria. African Journal of Teacher Education (AJOTE), Vol. 3, No. 1.

Osman, N. A. A. (2014). The acceptance and use of information and communication technologies by staff members in Khartoum state's universities, Ph.D. Thesis, Dresden University of Technology, Sudan.

Philip, A., Oluwaghema, C. \& Oluwaranti, A. (2010). An evaluation of the impact of information and communication technologies diffusion in Nigeria's higher educational institutions. Journal of Information technology, 4(1), 25-34.

Rosnaini, M. \& Mohd-Arif, H. I. (2010). Impact of training and experience in using ICT on inservice teachers' basic ICT literacy. Malaysian Journal of Education Technology, 10(2): $1-8$

Sharma, R. S., Samuel, E. M. \& Ng, E. (2009). Beyond the digital divide: Policy analysis for knowledge societies. Journal of Knowledge Management, 13(5), 373-386.

Suryawanshi, K. \& Narkhede, S. (2015). Green ICT for sustainable development: A higher education perspective. Procedia Computer Science, vol. 70, 701-707.

UNESCO (2011). Digital literacy in education, brief policy. Institute of Information Technologies in Education. 
(2014). Information and communication technology (ICT) in education in Asia: A comparative analysis of ICT integration and e-readiness in schools across Asia. Montreal: UNESCO Institute for http://www.uis.unesco.org/Communication/Documents/ICT-asia-en.pdf.

Voogt, J. (2010). A blended in-service arrangement for supporting science teachers in technology integration. Journal of Technology and Teacher Education, 18(1), 83-109.

Voogt, J., Fisser, P., Pareja Roblin, N., Tondeur, J. \& Van Braak, J. (2013). Technological pedagogical content knowledge - a review of the literature. Journal of Computer Assisted Learning, 29(2), 109-121.

Zhang, Q., Lu, C. \& Boutaba, R. (2010). Cloud computing: State-of-the-art and research challenges. Journal of Internet Services and Applications, 1(1), 7-18.

\section{Authors}

Sunday Nnamdi Okocha is a Computer and ICT personnel at the Institute of Education and a Ph.D. student of the International Centre for Educational Evaluation, Institute of Education, University of Ibadan, Ibadan, Nigeria. His research interests include: Educational evaluation, monitoring, quantitative analysis and comparative study on the adoption of modern ICT tools for effective delivery of educational activities at various levels of education.

Monica Ngozi Odinko is a Professor at the International Centre for Educational Evaluation, Institute of Education, University of Ibadan, Ibadan, Nigeria. Her research interests include: Evaluation of pre-school teaching and learning activities, comparative study of basic education, material provisions and learning resources and their use in teaching and learning, and instructional modes at the basic level of education. 